\title{
KOMISARIS KELUARGA, KOMISARIS WANITA DAN PENGUNGKAPAN MODAL INTELEKTUAL: STUDI PADA PERISTIWA PENAWARAN SAHAM PERDANA
}

\author{
FAMILY COMMISSIONERS, FEMALE COMMISSIONERS AND INTELLECTUAL CAPITAL DISCLOSURE: \\ EVIDENCE FROM INITIAL PUBLIC OFFERING
}

\author{
Doddy Setiawan ${ }^{* 1}$ dan Harviana Anggraini Putri*) \\ *) Fakultas Ekonomi dan Bisnis Universitas Sebelas Maret \\ J1. Ir. Sutami No.36A, Jebres, Kota Surakarta, Jawa Tengah 57126
}

\begin{abstract}
This study aims at examining the effect of family commissioners and female commissioners on intellectual capital disclosure using Indonesian context. There were three independent variables in the study: percentage of family commissioners on board of commissioners, family chairman of the board of commissioners, and female commissioners. The sample of the study consisted of non-financial firms that conducted Initially Public Offering (IPO) at Indonesia Stock Exchange (IDX) during the 2001 - 2016 period. The final sample of the study consisted of 175 firms. This study used multiple regression to test the effect of family commissioners and female commissioners on intellectual capital disclosure. The result of the study shows that female commissioners and percentage of family commissioners have positive effects on intellectual capital disclosure. Female commissioners have positive effects to push the company to provide more information to the investors. Therefore, gender diversity in the board of commissioners has a positive effect to the firms. Furthermore, family commissioners also push management to provide better disclosure on intellectual capital. However, this study did not find significant effects of family chairman on the board of commissioners on intellectual capital disclosure.
\end{abstract}

Keywords: intellectual capital disclosure, IPO, female commissioner, board of commissioners, family commissioners

\begin{abstract}
Abstrak: Penelitian ini bertujuan menguji pengaruh komisaris yang berasal dari keluarga pemilik perusahaan dan komisaris wanita terhadap pengungkapan modal intelektual. Variabel independen pada penelitian ini terdiri dari tiga variabel, yaitu proporsi komisaris keluarga di dewan komisaris, komisaris utama yang berasal dari keluarga dan komisaris wanita. Sampel penelitian ini terdiri dari perusahaan non-keuangan yang melakukan penjualan saham perusahaan untuk pertama kali di Bursa Efek Indonesia (BEI) periode 2001-2016. Perusahaan yang menjadi sampel berjumlah 175 perusahaan. Penelitian ini menggunakan regresi berganda untuk menguji dampak komisaris keluarga dan komisaris wanita terhadap pengungkapan modal intelektual. Hasil penelitian ini menunjukkan proporsi komisaris keluarga dan komisaris wanita berpengaruh signifikan terhadap pengungkapan modal intelektual. Komisaris wanita mampu memberikan dampak kepada manajemen untuk lebih banyak mengungkapkan informasi kepada investor. Hal ini menunjukkan diversitas gender di perusahaan mempunyai pengaruh yang positif terhadap perusahaan. Selanjutnya, komisaris keluarga juga menginginkan perusahaan mengungkapkan informasi mengenai modal intelektual lebih banyak. Akan tetapi, penelitian ini tidak menemukan dampak signifikan komisaris utama yang berasal dari keluarga terhadap pengungkapan modal intelektual.
\end{abstract}

Kata kunci: pengungkapan modal intelektual, IPO, komisaris wanita, dewan komisaris, komisaris keluarga

\footnotetext{
${ }^{1}$ Alamat Korespondensi:

Email: doddy.setiawan@staff.uns.ac.id
} 


\section{PENDAHULUAN}

Salah satu cara bagi perusahaan untuk memperoleh dana tambahan yang bisa dipergunakan untuk meningkatkan modal perusahaan adalah dengan melakukan penawaran saham ke pasar modal. Initial Public Offering (IPO) merupakan penawaran saham di pasar perdana yang dilakukan oleh perusahaan yang hendak go public (Hartono dan Ali, 2002). Investor bisa menggunakan kesempatan yang diberikan oleh perusahaan saat melakukan IPO untuk membeli saham, sehingga menjadi bagian dari pemilik perusahaan.

Untuk melakukan IPO, perusahaan perlu menyajikan laporan prospektus untuk mengungkapkan kondisi perusahaan. Prospektus ini merupakan sarana bagi perusahaan untuk menyajikan informasi yang penting tentang keadaan perusahaan (Hartono, 2017). Perusahaan dapat menggunakan prospektus sebagai sarana menyajikan informasi yang menarik sehingga bisa menarik lebih banyak calon investor. Investor tentu berharap perusahaan akan menyajikan informasi yang luas, sehingga bisa digunakan untuk melakukan pengambilan keputusan yang tepat. Di lain pihak, manajemen di dalam perusahaan tidak memberikan semua informasi tersebut. Jadi terdapat asimetri informasi antara manajemen dan investor. Kondisi ini disebut asimetri informasi antara manajemen dan investor (Chhabra et al. 2017).

Menjadi tugas perusahaan untuk lebih meningkatkan pengungkapan informasi keuangan dan non keuangan di dalam prospektus agar meminimalkan informasi yang heterogen antara investor institusi dengan investor individu, selain untuk mengurangi terjadinya informasi asimetri (asymmetric information). Asimetri informasi yang terjadi saat penawaran saham perdana mempunyai tingkat yang lebih tinggi dibandingkan dengan asimetri informasi saat perusahaan sudah terdaftar di bursa saham (Hartono, 2006). Salah satu pengungkapan informasi tambahan yang relevan untuk mengurangi informasi asimetri antara emiten dan berbagai partisipan di pasar modal adalah pengungkapan modal intelektual (Caputo et al. 2016). Pengungkapan modal intelektual yang memadai dapat mengurangi asimetri informasi pada saat penawaran saham perdana (Garanina dan Dumay, 2017).

Bontis (2001) menyebutkan bahwa modal intelektual merupakan kunci penentu penggerak nilai perusahaan dalam era ekonomi baru. Perusahaan yang berupaya mengoptimalkan sumber daya intelektual yang dimiliki dengan optimal akan menciptakan nilai tambah dan keunggulan kompetitif. Hal tersebut akan berdampak pada peningkatan efisiensi operasi (Lu et al. 2014) dan kinerja keuangan perusahaan (Pucci et al. 2015).

Salah satu kasus terkait dengan pentingnya pengungkapan modal intelektual menimpa Bank Rakyat Indonesia (Persero) Tbk diulas dalam situs berita online (republika.co.id) pada bulan Maret 2013. Perusahaan ini dituntut untuk menyelesaikan kewajibannya kepada pensiunan seperti uang pesangon, uang penghargaan masa kerja, dan uang penggantian hak. Kasus ini mengindikasikan kurangnya pengungkapan informasi yang menyeluruh mengenai kasus tersebut. Informasi tersebut dapat diungkapkan secara sukarela pada annual report sebagai informasi pendukung demi memenuhi kebutuhan informasi para stakeholder. Perusahaan dapat melakukan penjelasan tentang jumlah pengeluaran atau biaya yang dibelanjakan, untuk karyawan seperti biaya yang dibelanjakan untuk karyawan seperti biaya pendidikan dan pelatihan, pensiun, pengembangan kompetensi karyawan, dan biaya lainnya terkait dengan peningkatan kualitas karyawan.

Pengungkapan modal intelektual perlu untuk dilakukan oleh suatu perusahaan dikarenakan adanya permintaan transparansi yang meningkat di pasar modal sehingga informasi modal intelektual membantu investor menilai kemampuan perusahaan dengan lebih baik. Di Indonesia, pengungkapan modal intelektual sendiri masih bersifat sukarela (Rafinda et al. 2011). Pengungkapan modal intelektual dikomunikasikan kepada pemangku kepentingan internal dan external seperti investor dan kreditur, pengungkapan ini bertujuan untuk menciptakan nilai bagi perusahaan.

Meskipun praktik pengungkapan modal intelektual masih terhitung sedikit, namun seiring semakin pesatnya perkembangan modal intelektual, semakin menarik perhatian banyak pihak baik praktisi maupun akademisi. Penelitian-penelitian yang berfokus pada praktik pengungkapan modal intelektual pun telah banyak dilakukan. Misalnya Singh dan van der Zahn (2009), melakukan penelitian terhadap hubungan antara pengungkapan modal intektual pada prospektus IPO dengan post-issue kinerja saham. Mereka menemukan terdapat hubungan negatif antara pengungkapan modal intelektual pada prospektus IPO dengan post-issue kinerja saham. 
Rasmini et al. (2014) melakukan penelitian pada perusahaan keuangan yang tercatat di Bursa Efek Indonesia selama periode 2004-2009, hasilnya menyebutkan bahwa keragaman gender mempengaruhi pengungkapan modal intelektual. Hal ini sejalan dengan penelitian yang dilakukan Nadeem et al. (2017) dan Tejedo-Romero et al. (2017) menemukan bahwa kehadiran wanita di dewan direksi memiliki efek positif pada kinerja modal intelektual. Berbeda dengan penelitian yang dilakukan oleh Rodrigues et al. (2017) yang menyebutkan komisaris wanita tidak berpengaruh signifikan terhadap pengungkapan modal intelektual.

Widarjo (2011) menginvestigasi dampak pengungkapan modal intelektual terhadap nilai perusahaan setelah IPO. Hasil penelitiannya menunjukkan peningkatan pengungkapan modal intelektual akan memberikan peningkatan nilai perusahaan tersebut. Jadi pengungkapan modal intelektual memberikan pengaruh positif terhadap nilai perusahaan. Selain itu pengungkapan kepemilikan modal intelektual juga bisa mengurangi underpricing pada saat penawaran saham perdana (Widarjo et al. 2017). Warganegara (2011) melakukan penelitian untuk mengetahui pengaruh penjamin emisi multinasional terhadap modal intelektual. Penelitian ini menemukan bahwa perusahaan underwriting internasional secara positif mempengaruhi tingkat pengungkapan modal intelektual dalam prospektus IPO Indonesia. Underwriter dari luar negeri mampu menekan perusahaan di Indonesia untuk mengungkapkan modal intelektual lebih banyak. Penelitian yang dilakukan Shella dan Wedari (2016) menguji hubungan antara pengungkapan modal intelektual dan kinerja pasar perusahaan. Sampel penelitian mereka adalah perusahaan yang termasuk di LQ-45 pada periode 2012-2014. Hasilnya menunjukkan adanya dampak negatif pengungkapan modal intelektual terhadap kinerja perusahaan. Pengungkapan modal intelektual berbanding terbalik dengan kinerja perusahaan, pengungkapan yang semakin intensif justru mengakibatkan penurunan nilai perusahaan. Penelitian yang dilakukan oleh Santoso (2012) justru menunjukkan pengungkapan modal intelektual tidak berpengaruh terhadap kinerja perusahaan saat ini dan satu tahun ke depan.

Penelitian sebelumnya menunjukkan bahwa pengungkapan modal intelektual mempunyai dampak positif terhadap kinerja perusahaan (Lu et al. 2014, Pucci et al. 2015). Pengungkapan modal intelektual juga dapat mengurangi kesenjangan informasi pada saat perusahaan melakukan penawaran saham perdana (Garanina dan Dumay, 2017; Widarjo, 2011), sehingga bisa mengurangi underpricing pada saat penawaran saham perdana (Widarjo et al. 2017). Hal ini menunjukkan pentingnya pengungkapan modal intelelektual pada saat penawaran saham perdana. Penelitian mengenai pengungkapan modal intelektual pada saat perusahaan melaksanakan IPO masih jarang kecuali Garanina dan Dumay (2017), Widarjo (2011) dan Widarjo et al. (2017). Oleh karena itu, penelitian ini fokus pada pengungkapan modal intelektual saat penawaran saham perdana. Penelitian yang dilakukan kecuali Garanina dan Dumay (2017) dan Widarjo (2011) menguji dampak pengungkapan modal intelektual terhadap nilai perusahaan, sedangkan Widarjo et al. (2017) menguji dampak pengungkapan modal intelektual terhadap underpricing. Selain itu, Warganegara (2011) menguji dampak keberadaan penjamin emisi dari luar negeri terhadap underpricing. Penelitian sebelumnya belum menguji dampak komposisi dewan komisaris terhadap pengungkapan modal intelektual saat penawaran saham perdana. Oleh karena itu, penelitian ini mencoba mengisi gap ini dengan memfokuskan penelitian pada struktur dewan komisaris terhadap pengungkapan modal intelektual saat penawaran saham perdana. Secara lebih spesifik penelitian ini fokus pada komisaris wanita dan dan komisaris keluarga di dewan komisaris. Indonesia mempunyai konteks institusi yang unik dibandingkan degan negara lain, yaitu sebagian besar perusahaan di Indonesia dimiliki oleh keluarga (Carney dan Child, 2013; Setiawan et al. 2016). Keluarga pemilik yang mempunyai proporsi yang signifikan mampu menaruh anggota keluarga di dalam dewan komisaris. Penelitian ini mencoba menguji dampak dari anggota keluarga pemilik perusahaan yang menempati jabatan di dewan komisaris terhadap pengungkapan modal intelektual pada situasi yang penting yaitu pada saat perusahaan melakukan penawaran saham perdana. Hal ini merupakan salah satu hal yang membedakan penelitian ini dengan penelitian sebelumnya. Selain itu, Dieleman dan Aiswarhya (2012) mengungkapkan bahwa proporsi wanita di dewan komisaris dan dewan direksi di Indonesia berkisar $11 \%$. Hal ini termasuk di kategori yang tinggi untuk negara Asia sehingga penelitian ini juga menguji keberadaan komisaris wanita terhadap pengungkapan modal intelektual pada saat penawaran saham perdana. 
Penelitian ini fokus pada pengaruh komposisi dewan komisaris yaitu keberadaan komisaris keluarga di dewan komisaris, keberadaan komisaris utama yang berasal dari keluarga pemilik perusahaan dan keberadaan komisaris wanita terhadap pengungkapan modal intelektual. Ruang lingkup penelitian ini adalah fokus pada pengungkapan modal intelektual pada saat penawaran saham perdana di Indonesia pada periode 2001-2016.

Tujuan penelitian ini adalah menunjukkan bukti empiris pengaruh komisaris keluarga di dewan komisaris terhadap pengungkapan modal intelektual. Tujuan kedua penelitian ini adalah menunjukkan bukti empiris peran komisaris utama yang berasal dari keluarga pemilik perusahaan terhadap pengungkapan modal intelektual pada saat penawaran saham perdana. Tujuan pertama dan kedua terkait peran pemilik perusahaan dalam menempatkan anggotanya di dewan komisaris. Tujuan ketiga adalah memberikan bukti empiris mengenai pentingnya keberadaan komisaris wanita terhadap pengungkapan modal intelektual pada saat penawaran saham perdana. Untuk mencapai tujuan penelitian maka penelitian ini meneliti prospektus yang diterbitkan oleh perusahaan yang melakukan penawaran saham perdana di Bursa Efek Indonesia pada periode 2001-2016. Selanjutnya melakukan pengujian statistik dampak komisaris keluarga di dewan komisaris, komisaris utama yang berasal dari keluarga pemilik perusahaan dan komisaris wanita terhadap pengungkapan modal intelektual pada saat penawaran saham perdana.

\section{METODE PENELITIAN}

Data yang digunakan dalam penelitian ini adalah data sekunder. Penggunaan data sekunder dilakukan atas dasar pertimbangan bahwa perusahaan yang diteliti adalah perusahaan go public. Data sekunder dalam penelitian ini berupa laporan prospektus dari perusahaan yang tercatat di Bursa Efek Indonesia pada tahun 2001 sampai dengan 2016. Data terkait diperoleh dari situs resmi, Bursa Efek Indonesia www.idx.com. Penelitian ini akan menggunakan laporan prospektus yang diterbitkan setelah IPO oleh perusahaan tahun 2001 sampai dengan tahun 2016. Penggunaan range waktu tersebut dianggap dapat mewakili jumlah sampel yang dibutuhkan dalam penelitian ini.
Dalam penelitian ini, teknik pengambilan sampel menggunakan pertimbangan tertentu di mana umumnya disesuaikan dengan tujuan atau masalah penelitian. Kriteria-kriteria yang digunakan dalam sampel adalah sebagai berikut: (1) Perusahaan yang melakukan IPO pada tahun 2001 sampai dengan tahun 2016 di Bursa Efek Indonesia. (2) Perusahaan non keuangan yang melakukan IPO pada tahun 2001 sampai dengan tahun 2016 di Bursa Efek Indonesia.

Dalam penelitian ini variabel dependen yang digunakan adalah pengungkapan modal intelektual pada laporan prospektus saat IPO. Pengukuran pengungkapan modal menggunakan indeks yang dikembangkan oleh Singh dan van der Zahn (2008). Singh dan van der Zahn (2008) mengaplikasikan pengukuran indeksnya pada perusahaan yang memutuskan untuk menjual saham untuk pertama kali di bursa saham, sehingga indeks yang dikembangkan oleh Singh dan van der Zahn (2008) lebih sesuai dengan konteksi penelitian ini. Selain itu, indeks ini lebih komprehensif jika dibandingkan dengan indeks pengungkapan modal intelektual yang dikembangkan oleh Abdolmohammadi (2005) dan Bukh et al. (2005). Indeks yang dikembangkan oleh Singh dan van der Zahn (2008) memiliki 81 item yang dapat dibagi menjadi sumber daya manusia, pelanggan, informasi teknologi, proses, riset dan pengembangan dan pernyataan strategis.

Pengukuran indeks pengungkapan modal intelektual menggunakan analisis content. Analisis ini memberikan skor 1 apabila perusahaan mengungkapkan informasi yang sesuai dengan item berdasarkan indeks yang dikembangkan Singh dan van der Zahn (2008), jika perusahaan tidak mengungkapkan informasi tersebut maka skor untuk item tersebut adalah 0. Skor dari item yang telah dinilai akan dijumlahkan sebagai skor total pengungkapan modal intelektual. Selanjutnya skor pengungkapan untuk masing-masing perusahaan akan dibagi dengan 81 , yaitu nilai maksimal apabila semua item memperoleh nilai 1 . Rasio ini merupakan rasio pengungkapan modal intelektual perusahaan.

Variabel independen yang digunakan di penelitian ini adalah proporsi gender dewan komisaris, proporsi keluarga dalam dewan komisaris dan komisaris utama yang termasuk keluarga pemilik perusahaan sedangkan variabel kontrol dalam penelitian ini adalah return on assets (ROA), ukuran perusahaan (SIZE), leverage (LEV), dan umur perusahaan (AGE). Proporsi komisaris wanita diukur dengan menggunakan persentase 
komisaris wanita dari seluruh anggota dewan komisaris perusahaan (Terjesen et al. 2016). Proporsi keluarga dalam dewan komisaris diukur dengan menggunakan semua keterlibatan keluarga mencakup jumlah anggota keluarga dan perwakilan keluarga. Anggota keluarga adalah jumlah anggota keluarga (melalui darah atau pernikahan) memegang jabatan direktur atau manajemen (Prabowo dan Simpson, 2011; Chen et al. 2013). Komisaris utama yang termasuk keluarga pemilik perusahaan adalah variabel dummy yang setara dengan satu ketika anggota keluarga memegang posisi komisaris utama (Chen et al. 2013). Untuk mengukur komisaris utama yang termasuk keluarga pemilik perusahaan menggunakan menggunakan variabel dummy, jika komisaris utama merupakan bagian dari keluarga pemilik perusahaan diberi nilai 1 dan jika tidak maka 0.

\section{Hubungan Kendali Keluarga dalam Dewan Komisaris dengan Pengungkapan Modal Intelektual}

Darmadi dan Sodikin (2013) menyatakan bahwa kontrol keluarga secara negatif dan signifikan mempengaruhi tingkat keterbukaan informasi. Perusahaan yang dikontrol keluarga memiliki motivasi rendah untuk mengungkapkan informasi sukarela tambahan, yang mungkin secara tak terduga mengekspos keuntungan pribadi yang dikelola oleh keluarga pengawas.

Hal ini sejalan dengan penelitian yang dilakukan oleh Chen dan Jaggi (2000) yang menunjukkan perusahaan dengan kontrol keluarga lebih memilih untuk tidak mengungkapkan informasi yang lebih luas dalam laporan tahunan mereka, dan membatasi pengungkapan informasi tertentu hanya untuk mereka yang terlibat dalam pengelolaan perusahaan dan pihak lain yang memberikan pembiayaan bagi perusahaan. Nekhili et al. (2012) juga menemukan bahwa kendali keluarga dalam perusahaan berpengaruh negatif terhadap pengungkapan sukarela. Berdasarkan dari uraian hasil penelitian di atas, dapat dirumuskan dua hipotesis sebagai berikut:

H1 : Proporsi keluarga dalam dewan komisaris berpengaruh negatif terhadap tingkat pengungkapan modal intelektual

H2 : Komisaris utama yang termasuk keluarga pemilik perusahaan berpengaruh negatif terhadap tingkat pengungkapan modal intelektual.

\section{Hubungan Proporsi Komisaris Wanita dengan Pengungkapan Modal Intelektual}

Proporsi keberadaan wanita di dalam jajaran dewan komisaris banyak mendapatkan perhatian dari peneliti. Wanita diharapkan memberikan nilai yang lebih bagi perusahaan karena wanita mempunyai pola pikir yang lebih detail. Proses pengambilan keputusan dengan lebih hati-hati dan berdasarkan proses yang detail akan memberikan manfaat bagi perusahaan (Robbins dan Judge, 2013). Proses pengambilan keputusan ini diharapkan memberikan keputusan yang lebih baik, karena wanita lebih seksama dalam melakukan analisis untuk mengambil keputusan. Selain itu keberadaan wanita akan memberikan sinyal kepada pasar bahwa perusahaan mempunyai kebijakan yang lebih komprehensif, sehingga bisa memberikan nilai lebih bagi perusahaan (Brammer et al. 2007). Robbins dan Judge (2013) menyatakan bahwa wanita pada umumnya lebih memiliki pemikiran yang mendetail terkait dalam analisis pengambilan keputusan. Mereka cenderung menganalisis masalah-masalah sebelum membuat suatu keputusan dan mengolah keputusan yang telah dibuat, sehingga menghasilkan pertimbangan masalah serta alternatif penyelesaian yang lebih saksama.

Rasmini et al. (2014) menunjukkan keberadaan wanita memberikan dampak positif terhadap pengungkapan modal intelektual. Hasil ini juga diperkuat oleh Nadeem et al. (2017) dan Tejedo-Romero et al. (2017) yang menunjukkan keberadaan direksi wanita memperluas pengungkapan modal intelektual perusahaan. Kinerja pengungkapan modalyang baik akan meningkatkannilai perusahaan (Widarjo, 2011; Pucci et al. 2015). Selain itu keberadaan komisaris wanita juga memberikan nilai tambah bagi perusahaan (Green dan Homroy, 2018). Nalikka (2009) menemukan bahwa diversitas gender berpengaruh positif pada pengungkapan sukarela. Berdasarkan dari uraian hasil penelitian di atas, hipotesis yang dapat dirumuskan adalah sebagai berikut:

H3 : Proporsi komisaris wanita berpengaruh positif terhadap tingkat pengungkapan modal intelektual

Kerangka pemikiran penelitian menunjukkan pengaruh variabel dependen. Variabel dependen dalam penelitian ini adalah pengungkapan modal intelektual, sedangkan variabel independen dalam penelitian ini adalah proporsi komisaris wanita, proporsi keluarga dalam dewan komisaris dan komisaris utama yang termasuk keluarga. Kemudian variabel kontrol dalam penelitian 
ini adalah ROA, ukuran perusahaan, leverage, dan umur perusahaan. Berdasarkan rumusan masalah yang telah di uraikan sebelumnya, kerangka pemikiran dalam penelitian ini pada Gambar 1.

Berdasarkan Gambar 1 maka dalam penelitian ini variabel independen, yaitu proporsi komisaris wanita, proporsi keluarga dalam dewan komisaris dan komisaris utama yang termasuk keluarga pemilik perusahaan akan diuji pengaruhnya terhadap pengungkapan modal intelektual perusahaan. Variabel kontrol yaitu ROA, ukuran perusahaan, leverage, dan umur perusahaan digunakan untuk membandingkan hasil pengaruhnya dengan variabel yang akan diteliti terhadap variabel dependen yang menjadi isu utama penelitian ini, variabel kontrol berperan sebagai independen variabel pada ranah uji statistika, akan tetapi pada tataran metodologi, hal ini disebut variabel kontrol.

\section{HASIL}

Penelitianinimenggunakan datasekunderberupalaporan prospektus tahun 2001-2016 yang dipublikasikan oleh website resmi Bursa Efek Indonesia (BEI). Ada 240 perusahaan non-keuangan yang melakukan IPO di BEI pada tahun 2001-2016. Sampel penelitian ini terdiri dari perusahaan non-keuangan yang melakukan IPO di BEI pada periode tahun 2001-2016 dan menerbitkan prospektus secara lengkap.
Tabel 1 mengungkapkan proses pemilihan sampel yang dilakukan dalam penelitian ini. Setelah penyeleksian sampel berdasarkan pemenuhan kriteria yang telah ditentukan, tersisa 175 perusahaan. Setelah sampel memenuhi kriteria yang ditentukan, maka proses scoring untuk pengungkapan modal intelektual bisa dilakukan. Setiap item pengungkapan modal intelektual yang diungkapkan akan diberi skor 1 , sedangkan item yang tidak diungkapkan diberi skor 0 .

\section{Statistik Deskriptif}

Statistik deskriptif penelitian ini mengungkapkan informasi mengenai karakteristik variabel yang digunakan di penelitian ini seperti nilai tengah, nilai maksimum, nilai terendah dan standar deviasi. Tabel 2 menginformasikan mengenai statistik deskriptif variabel penelitian.

Tabel 2 menunjukkan nilai mean pengungkapan modal intelektual adalah sebesar 33,07\%. Hal ini menunjukkan dari 81 item pengungkapan modal intelektual, rata-rata perusahaan yang melakukan IPO mengungkapkan sekitar 27 item. Secara umum, angka ini menandakan pengungkapan modal intelektual saat penawaran saham perdana di Indonesia masih cukup rendah. Selanjutnya nilai tertinggi untuk pengungkapan modal intelektual adalah 55 item atau mempunyai nilai rasio sebesar $68 \%$. Nilai rasio pengungkapan modal intelektual adalah sebsar $12,34 \%$ saja.

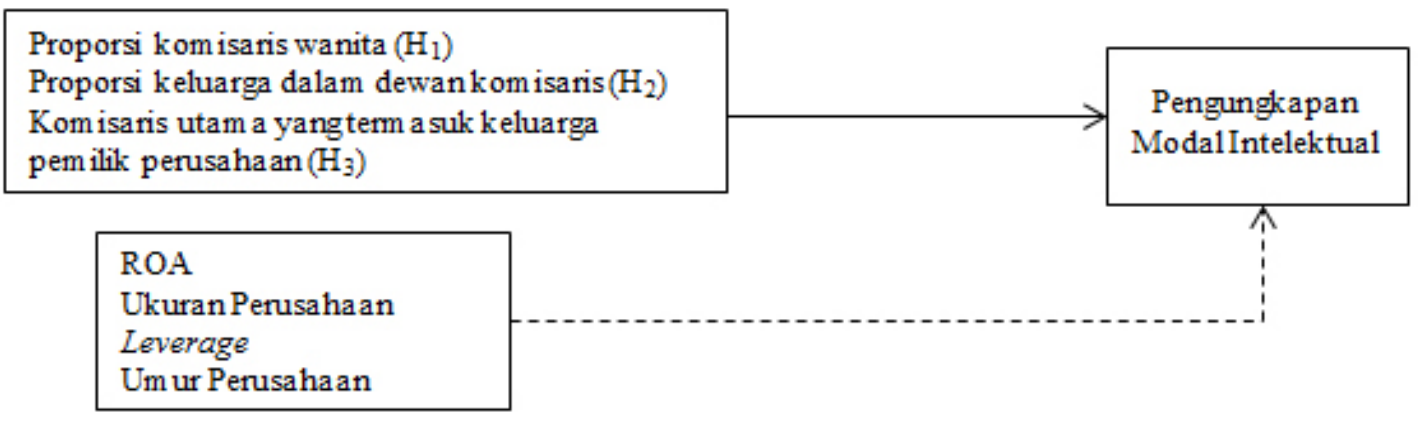

Gambar 1. Kerangka pemikiran penelitian

Tabel 1. Pemilihan sampel

\begin{tabular}{lc}
\hline Keterangan & Jumlah \\
\hline Perusahaan non keuangan yang melakukan IPO dan terdaftar di BEI tahun 2001-2016 & 240 \\
Perusahaan non keuangan melakukan IPO dan terdaftar di BEI tahun 2001-2016 yang tidak menerbitkan & (58) \\
prospektus secara lengkap & \\
$\begin{array}{l}\text { Perusahaan non keuangan yang melakukan IPO dan terdaftar di BEI tahun 2001-2016 yang tidak } \\
\text { memenuhi kriteria untuk dijadikan sampel }\end{array}$ & (7) \\
\hline Sampel akhir penelitian & 175 \\
\hline
\end{tabular}


Tabel 2. Statistik deskriptif

\begin{tabular}{lccccc}
\hline & $\mathrm{N}$ & Minimum & Maximum & Mean & Std. Deviation \\
\hline ICD & 175 & 12,346 & 67,901 & 33,02995 & 12,217458 \\
Komisaris Wanita & 175 & 0 & 100 & 14,25476 & 22,279260 \\
Keluarga dalam DK & 175 & 0 & 80,000 & 14,35666 & 18,843328 \\
Ukuran & 175 & 23,393 & 30,679 & 27,33980 & 1,498258 \\
Usia & 175 & 2 & 90 & 16,84 & 12,827 \\
Leverage & 175 & 0,069 & 28,824 & 2,20598 & 2,889386 \\
ROA & 175 & $-0,0030$ & 1,2380 & 0,071137 & 0,1127419 \\
\hline $\mathrm{N}$ & 175 & & & &
\end{tabular}

Keterangan: ICD (Pengungkapan modal intelektual); Komisaris wanita (jumlah wanita dalam dewan komisaris); Keluarga dalam DK (Proporsi keluarga dalam dewan komisaris); Ukuran (Ukuran perusahaan); Usia (Usia perusahaan); Leverage (Leverage); ROA (Return on assets).

Nilai mean gender dewan komisaris perusahaan sampel sebesar 14,60 dengan standar deviasi sebesar 22,16. Nilai mean proporsi keluarga dalam dewan komisaris perusahaan sampel sebesar 14,39 dengan standar deviasi sebesar 18,74. Nilai mean komisaris utama yang termasuk keluarga perusahaan sampel sebesar 0,58 dengan standar deviasi sebesar 0,49 (Tabel 3). Variabel komisaris utama yang termasuk keluarga pemilik perusahaan merupakan variabel dummy, yang mempunyai nilai 0 apabilai komisaris utama bukan bagian dari keluarga pemilik dan 1 apabila komisaris utama berasal dari keluarga pemilik perusahaan. Untuk variabel kontrol, ukuran perusahaan mempunyai nilai mean sebesar 27,35 dengan nilai maksimum sebesar 30,67 dan nilai minimumnya sebesar 23,67 Usia perusahaan mempunyai nilai mean sebesar 16,94 dengan nilai maksimum sebesar 90 tahun dan nilai minimumnya 1 tahun. Leverage, mempunyai nilai mean sebesar 9,9 dengan nilai minimum sebesar $-85,18$ dan nilai maksimumnya sebesar 28,82 . Variabel terakhir yaitu ROA, dengan nilai mean sebesar $0,06 \%$ dengan nilai maksimum sebesar $1,23 \%$ dan nilai minimumnya sebesar $0,0030 \%$.

\section{Pengujian Hipotesis}

Hasil uji hipotesis menunjukkan proporsi keluarga dalam dewan komisaris berpengaruh positif terhadap pengungkapan modal intelektual. Hipotesis kedua ditolak. Temuan ini bertolak belakang dengan hasil penelitian Darmadi dan Sodikin (2013), yang menyatakan bahwa adanya kendali keluarga dalam perusahaan berpengaruh negatif terhadap luasnya pengungkapan. Namun, sejalan dengan penelitian yang dilakukan oleh Ali et al. (2007), dimana adanya kendali keluarga dalam perusahaan berpengaruh positifterhadap pengungkapan. Perusahaan dengan dewan komisaris yang merupakan keluarga pendiri perusahaan akan bertanggung jawab atas perusahaan keluarga dengan menunjukkan praktik pengungkapan yang lebih baik. Perwakilan keluarga pemilik perusahaan yang menjadi anggota dalam dewan komisaris dapat melakukan pengawasan dan mempengaruhi manajemen untuk melakukan pengungkapan modal intelektual yang lebih tinggi. Penelitian yang dilakukan oleh Su dan Carney (2013) menemukan bahwa perusahaan keluarga berusaha meningkatkan modal intelektualnya untuk memperoleh keunggulan kompetitif. Perusahaan yang dimiliki oleh keluarga mempunyai kecenderungan untuk mengungkapkan informasi lebih banyak untuk kepentingan investor (Wan-Hussin, 2009). Pihak keluarga menunjukkan bahwa mereka juga mempunyai perhatian yang signifikan terhadap investor, sehingga mau melakukan pengungkapan yang lebih banyak. Penelitian yang dilakukan oleh Al-Akra dan Hutchinson (2013) juga menunjukkan semakin tinggi kepemilikan keluarga berpengaruh positif terhadap pengungkapan.

Hasil uji hipotesis menunjukan bahwa variabel komisaris utama yang termasuk keluarga pemilik perusahaan (Keluarga Komut) tidak berpengaruh terhadap pengungkapan modal intelektual. Hipotesis ketiga ditolak. Hasil penelitian tidak mendukung hasil penelitian Darmadi dan Sodikin (2013) yang menemukan terdapat pengaruh negatif kendali keluarga dalam perusahaan terhadap pengungkapan. Penelitian ini juga tidak mendukung penelitian sebelumnya seperti Chen dan Jaggi (2000) dan Nekhili et al. (2012) yang menemukan dampak negatif kepemilikan keluarga terhadap kinerja perusahaan. Akan tetapi hasil penelitian ini sejalan dengan O'Boyle dan Pollack (2012) yang menunjukkan bahwa kepemilikan keluarga tidak berpengaruh signifikan terhadap kinerja. Tidak ada dampak kepemilikan keluarga atau perwakilan 
keluarga dalam perusahaan terhadap kinerja. Jadi perwakilan keluarga dalam hal ini Komisaris Utama juga tidak berpengaruh terhadap penyajian informasi modal intelektual.

Hasil uji (Tabel 4) menunjukkan bahwa pengujian variabel proporsi komisaris wanita (gender) mempunyai nilaisignifikansisebesar 0,017 . Artinya, nilaisignifikansi variabel gender dewan komisaris dibawah 0,05 sehingga pengujian memberikan hasil yang signifikan. Dengan demikian dapat disimpulkan bahwa proporsi komisaris wanita berpengaruh positif terhadap pengungkapan modal intelektual. Hipotesis pertama diterima. Hasil ini mendukung penelitian yang dilakukan oleh Nadeem et al. (2017), Rasmini et al. (2014) dan Tejedo-Romero et al. (2017) yang menemukan keberadaan wanita dalam dewan berpengaruh positif pada kinerja modal intelektual termasuk pengungkapan. Nalikka (2009) juga menemukan bahwa diversitas gender berpengaruh positif pada pengungkapan sukarela. Interpretasi dari variabel ini adalah wanita pada umumnya lebih memiliki pemikiran yang mendetail terkait dalam analisis pengambilan keputusan. Mereka cenderung menganalisis masalah-masalah sebelum membuat suatu keputusan dan mengolah keputusan yang telah dibuat, sehingga menghasilkan pertimbangan masalah serta alternatif penyelesaian yang lebih saksama (Robbins dan Judge, 2013). Hal ini membuat keberadaan wanita dalam dewan dapat memperluas pengungkapan modal intelektual perusahaan.

Tabel 3. Statistik deskriptif untuk variabel dummy

\begin{tabular}{lcc}
\hline & Frequency 0 & Frequency 1 \\
\hline $\begin{array}{l}\text { Komisaris utama yang } \\
\text { termasuk keluarga }\end{array}$ & 0,42 & 0,58 \\
$\mathrm{~N}$ & 175 & \\
\hline
\end{tabular}

Keterangan: Komisaris utama yang termasuk keluarga pemilik perusahaan $=$ Variabel independen berupa variabel dummy yang menggambarkan komisaris utama merupakan bagian dari keluarga/pemilik perusahaan, yang apabila bagian dari keluarga/pemilik perusahaan maka bernilai $=1$ dan benilai 0 apabila bukan bagian dari keluarga/pemilik perusahaan.

Tabel 4. Hasil Regresi

\begin{tabular}{|c|c|c|c|c|c|c|c|c|}
\hline & $\beta$ & thitung & $\beta$ & thitung & $\beta$ & thitung & $\mathrm{B}$ & thitung \\
\hline & \multicolumn{2}{|c|}{1} & \multicolumn{2}{|c|}{2} & \multicolumn{2}{|c|}{3} & \multicolumn{2}{|c|}{4} \\
\hline \multirow[t]{2}{*}{$\alpha$} & $-60,834$ & $-3,630$ & $-55,294$ & $-3,289$ & $-54,346$ & $-3,344$ & $-45,691$ & $-2,735$ \\
\hline & & 0,000 & & 0,001 & & 0,001 & & 0,007 \\
\hline \multirow[t]{2}{*}{ Komisaris Wanita } & 0,080 & 2,050 & 0,081 & 2,043 & & & & \\
\hline & & $0,021 b$ & & $0,021 b$ & & & & \\
\hline \multirow[t]{2}{*}{ Keluarga dalam DK } & 0,136 & 2,998 & & & 0,139 & 3,065 & & \\
\hline & & $0,001 \mathrm{a}$ & & & & $0,001 \mathrm{a}$ & & \\
\hline \multirow{2}{*}{$\begin{array}{l}\text { Komisaris utama yang } \\
\text { termasuk keluarga }\end{array}$} & $-1,048$ & $-0,602$ & & & & & $-0,865$ & $-0,484$ \\
\hline & & 0,274 & & & & & & 0,314 \\
\hline \multirow[t]{2}{*}{ Ukuran } & 3,251 & 5,374 & 3,101 & 5,053 & 3,038 & 5,103 & 2,819 & 4,618 \\
\hline & & $0,000 \mathrm{a}$ & & $0,000 \mathrm{a}$ & & $0,000 \mathrm{a}$ & & $0,000 \mathrm{a}$ \\
\hline \multirow[t]{2}{*}{ Usia } & 0,112 & 1,678 & 0,103 & 1,512 & 0,108 & 1,604 & 0,102 & 1,475 \\
\hline & & $0,095 \mathrm{c}$ & & 0,132 & & 0,111 & & 0,142 \\
\hline \multirow[t]{2}{*}{ Leverage } & $-0,154$ & $-0,513$ & $-0,184$ & $-0,6$ & $-0,197$ & $-0,653$ & $-0,231$ & $-0,744$ \\
\hline & & 0,609 & & 0,55 & & 0,514 & & 0,458 \\
\hline \multirow[t]{2}{*}{ ROA } & 13,516 & 1,747 & 14,935 & 1,909 & 13,143 & 1,708 & 13,306 & 1,666 \\
\hline & & $0,083 \mathrm{c}$ & & $0,058 \mathrm{c}$ & & $0,09 \mathrm{c}$ & & $0,098 \mathrm{c}$ \\
\hline $\mathrm{N}$ & & 175 & & 175 & & 175 & & 175 \\
\hline Adjt R2 & & 0,172 & & 0,135 & & 0,161 & & 0,115 \\
\hline F statistic & & 6,165 & & 6,442 & & 7,655 & & 5,527 \\
\hline
\end{tabular}

Keterangan: ${ }^{\text {a) }}$ signifikan pada $1 \%$; ${ }^{\text {b) }}$ signifikan pada $5 \%$; ${ }^{\text {c) signifikan } 10 \%}$ 
Hasil pengujian variabel kontrol menunjukkan ukuran perusahaan, usia perusahaan dan ROA berpengaruh positif terhadap pengungkapan modal intelektual. Perusahaan yang mempunyai ukuran besar cenderung menyajikan pengungkapan mengenai modal intelektual lebih lengkap. Selanjutnya, perusahaan yang memperoleh laba tinggi dan usia yang lebih lama juga mempunyai dampak positif terhadap pengungkapan modal intelektual. Hasil ini sesuai dengan Thoriq et al. (2018) yang menunjukkan ROA dan usia perusahaan berpengaruh signifikan terhadap underpricing pada saat melakukan penawaran saham perdana. Akan tetapi, penelitian ini tidak menemukan dampak signifikan leverage terhadap pengungkapan modal intelektual.

\section{Implikasi Manajerial}

Implikasi dari penelitian ini pertama, perusahaan sebaiknya memiliki dewan komisaris yang mempunyai diversitasgender.Komisariswanitaterbuktiberpengaruh positif terhadap luas pengungkapan modal intelektual. Oleh karena itu, perusahaan sebaiknya mengangkat komisaris wanita di dalam dewan komisaris untuk meningkatkan efektifitas kinerja dewan komisaris. Selain itu, keberadaan anggota dewan komisaris yang berasal dari keluarga pemilik juga menunjukkan peningkatan luas pengungkapan modal intelektual.

\section{KESIMPULAN DAN SARAN}

\section{Kesimpulan}

Proporsi keluarga dalam dewan komisaris berpengaruh positif terhadap pengungkapan modal intelektual. Hasil ini bertolak belakang dengan hasil penelitian Darmadi dan Sodikin (2013), yang menyatakan bahwa adanya kendali keluarga dalam perusahaan berpengaruh negatif terhadap luasnya pengungkapan. Namun sejalan dengan penelitian yang dilakukan oleh Ali et al. (2007), dimana perusahaan dengan dewan komisaris yang merupakan keluarga pendiri perusahaan akan bertanggung jawab atas perusahaan keluarga dengan menunjukkan praktik pengungkapan yang lebih baik.

Komisaris utama yang termasuk keluarga pemilik perusahaan tidak berpengaruh terhadap pengungkapan modal intelektual. Hasil penelitian tidak mendukung hasil penelitian Darmadi dan Sodikin (2013) yang menemukan terdapat pengaruh negatif komisaris utama yang termasuk keluarga pemilik perusahaan terhadap pengungkapan. Dari hasil analisis data yang telah dilakukan dapat disimpulkan bahwa, proporsi dewan komisaris wanita berpengaruh positif terhadap pengungkapan modal intelektual. Hasil ini mendukung penelitian yang dilakukan oleh Nadeem et al. (2017), Rasmini et al. (2014) dan Tejedo-Romero et al. (2017) yang menemukan keberadaan wanita dalam dewan berpengaruh positif pada pengungkapan modal intelektual.

\section{Saran}

Keterbatasan penelitian ini adalah penelitian ini fokus padakendali keluarga di dewan komisaris saja. Indonesia menggunakan sistem dua dewan: dewan komisaris dan dewan direksi. Dewan komisaris berfungsi untuk melakukan pengawasan terhadap dewan direksi. Oleh karena itu, penelitian selanjutnya bisa menguji dampak direksi yang berasal dari keluarga pemilik perusahaan dan direksi perempuan terhadap pengungkapan modal intelektual. Keterbatasan berikutnya adalah penelitian ini fokus pada struktur dewan komisaris, sehingga tidak menguji dampak struktur kepemilikan. Penelitian sebelumnya menunjukkan pentingnya struktur kepemilikan terhadap keputusan investasi perusahaan (Setiawan et al. 2016). Oleh karena itu, penelitian selanjutnya bisa menguji dampak struktur kepemilikan terhadap pengungkapan modal intelektual saat penawaran saham perdana.

\section{DAFTAR PUSTAKA}

Abdolmohammadi M J. 2005. Intellectual capital disclosure and market capitalization. Journal of Intellectual Capital 6(3): 397-416. https://doi. org/10.1108/14691930510611139.

Al-Akra M, Hutchinson P. 2013. Family firm disclosure and accounting regulation reform in the Middle East: The case of Jordan. Research in Accounting Regulation 25(1):101-107. https:// doi.org/10.1016/j.racreg.2012.11.003.

Ali A, Chen, T-Y, Radhakhrisnan, S. 2007. Corporate disclosures by family firms. Journal of Accounting and Economics 44(1): 238-286. https://doi.org/10.1016/j.jacceco.2007.01.006.

Bontis N. 2001. Assessing knowledge assets: a review of the models used to measure intellectual capital. International Journal of Management Reviews 3(1): 41-60. https://doi.org/10.1111/14682370.00053 . 
Brammer S, Millington A, Rayton B. 2007. The contribution of corporate social responsibility to organizational commitment. The International Journal of Human Resource Management, 18(10): 1701-1719. https://doi. org/10.1080/09585190701570866.

Bukh P N, Nielsen C, Gormsen P, Mouritsen J. 2005. Disclosure of information on intellectual capital in Danish IPO prospectuses. Accounting, Auditing \& Accountability Journal 18(6): 713-732. https://doi.org/10.1108/09513570510627685.

Caputo F, Giudice M D, Evangelista F, Russo G. 2016. Corporate disclosure and intellectual capital: the light side of information asymmetry. International Journal of Managerial and Financial Accounting 8(1): 75-96. https://doi. org/10.1504/IJMFA.2016.076668.

Carney R W, Child T B. 2013. Changes to the ownership and control of East Asian corporations between 1996 and 2008: The primacy of politics. Journal of Financial Economics 107(2): 494-513. https:// doi.org/10.1016/j.jfineco.2012.08.013.

Chen CJP, Jaggi B. 2000. Association between independent non-executive directors, family control and financial disclosures in Hong Kong. Journal of Accounting and Public Policy 19(4-5): 285-310. https://doi.org/10.1016/ S0278-4254(00)00015-6.

Chen ET, Gray S, Nowland J. 2013. Family representatives in family firms. Corporate Governance: An International Review 21(3): $242-263$. https://doi.org/10.1111/corg.12009.

Chhabra S, Kiran R, Sah AN. 2017. Information asymmetry leads to underpricing: validation through SEM for Indian IPOs. Program 51(2): 116-131.https://doi.org/10.1108/PROG-012016-0009.

Darmadi S, Sodikin A. 2013. Information disclosure by family-controlled firms: The role of board independence and institutional ownership. Asian Review of Accounting 21(3): 223-240. https:// doi.org/10.1108/ARA-01-2013-0009.

Dieleman M, Aishwarya M. 2012. Indonesia boardroom diversity report 2012: Female footprints in IDX listed companies. National University of Singapore.

GaraninaT, Dumay J.2017. Forward-looking intellectual capital disclosure in IPOs: Implications for intellectual capital and integrated reporting. Journal of Intellectual Capital 18(1): 128-148. https://doi.org/10.1108/JIC-05-2016-0054.
Green CP, Homroy S. 2018. Female directors, board committees and firm performance. European Economic Review 102: 19-38. https://doi. org/10.1016/j. euroecorev.2017.12.003.

Hartono. 2006. Analisis retensi kepemilikan pada penerbitan saham perdana sebagai sinyal nilai perusahaan. Jurnal Bisnis dan Manajemen 6(2): 141-162.

Hartono J. 2017. Teori Portofolio dan Analisis Investasi, Yogyakarta: BPFE Yogyakarta.

Hartono J, Ali S. 2002. Analisis pengaruh pemilihan metode akuntansi terhadap pemasukan penawaran perdana. Journal of Indonesian Economy and Business 17(2): 211-225.

Lu W.-M, Wang W-K, Kweh Q L. 2014. Intellectual capital and performance in the Chinese life insurance industry. Omega 42(1): 65-74. https:// doi.org/10.1016/j.omega.2013.03.002.

Nadeem M, De Silva T-A, Gan C, Zaman R. 2017. Boardroom gender diversity and intellectual capital efficiency: evidence from China. Pacific Accounting Review 29(4): 590-615. https://doi. org/10.1108/PAR-08-2016-0080.

Nalikka A. 2009. Impact of Gender Diversity on Voluntary Disclosure in Annual Reports. Journal of Accounting \& Taxation 1(1): 101-113.

Nekhili M, Boubaker S, Lakhal F. 2012. Ownership structure, voluntary R\&D disclosure and market value of firms: the French case. International Journal of Business 17(2): 126 - 140.

O'Boyle Jr EH, Pollack JM, Rutherford MW. 2012. Exploring the relation between family involvement and firms' financial performance: A meta-analysis of main and moderator effects. Journal of Business Venturing 27(1): 1-18. https://doi.org/10.1016/j.jbusvent.2011.09.002.

Prabowo MA, Simpson J. 2011. Independent directors and firm performance in family controlled firms: Evidence from Indonesia. Asian-Pacific Economic Literature 25(1): 121-132. https://doi. org/10.1111/j.1467-8411.2011.01276.x.

Pucci T, Simoni C, Zanni L. 2015. Measuring the relationship between marketing assets, intellectual capital and firm performance. Journal of Management \& Governance 19(3): 589-616. https://doi.org/10.1007/s10997-013-9278-1.

Rafinda A, Pramuka B, Kusuma P. 2011. Tren dan Variasi Intellectual Capital Disclosure pada Perusahaan-perusahaan Perbankan di Eropa Simposium Nasional Akuntansi XIV. Banda Aceh. 
Rasmini NK, Wirakusuma MG, Yuniasih NW. 2014. The effect of board diversity on the extent of intellectual capital disclosure (Empirical study in Indonesian Stocks Exchange). Asia Pacific Journal of Accounting and Finance 3(1): 4558.

Robbins SP, Judge TA. 2013. Organizational Behavior, New Jersey, USA: Prentice Hall.

Rodrigues LL, Tejedo-Romero F, Craig R. 2017. Corporate governance and intellectual capital reporting in a period of financial crisis: Evidence from Portugal. International Journal of Disclosure and Governance 14(1): 1-29. https:// doi.org/10.1057/jdg.2015.20.

Santoso S. 2012. Pengaruh modal intelektual dan pengungkapannya terhadap kinerja perusahaan. Jurnal Akuntansi dan Keuangan 14(1):16-31. https://doi.org/10.9744/jak.14.1.16-31.

Setiawan D, Bandi, Phua LK, Trinugroho I. 2016. Ownership structure and dividend policy in Indonesia. Journal of Asia Business Studies 10(3): 230-252. https://doi.org/10.1108/JABS05-2015-0053.

Shella S, Wedari LK. 2016. Intellectual capital dan intellectual capital disclosure terhadap market performance pada perusahaan publik indeks LQ45. Jurnal Akuntansi dan Auditing Indonesia 20(1): 27-36. https://doi.org/10.20885/jaai. vol20.iss 1.art3.

Singh I, van der Zahn JLWM. 2009. Intellectual capital prospectus disclosure and post-issue stock performance. Journal of Intellectual Capital 10(3): 425-450. https://doi. org/10.1108/14691930910977824.

Singh I, van der Zahn JLWM. 2008. Determinants of intellectual capital disclosure in prospectuses of initial public offerings. Accounting and Business Research 38(5): 409-431. https://doi.org/10.108 0/00014788.2008.9665774.

Su E, Carney M. 2013. Can China's family firms create intellectual capital? Asia Pacific Journal of Management 30(3): 657-675. https://doi. org/10.1007/s10490-012-9302-z.

Tejedo-RomeroF, Rodrigues LL, Craig R. 2017. Women directors and disclosure of intellectual capital information. European Research on Management and Business Economics 23(3): 123-131. https:// doi.org/10.1016/j.iedeen.2017.06.003.

Terjesen S, Couto EB, Francisco PM. 2016. Does the presence of independent and female directors impact firm performance? A multi-country study of board diversity. Journal of Management \& Governance 20(3): 447-483. https://doi. org/10.1007/s10997-014-9307-8.

Thoriq NK, Hartoyo S, Sasongko H. 2018. Faktor internal dan eksternal yang memengaruhi underpricing pada saat IPO di Bursa Efek Indonesia. Jurnal Aplikasi Manajemen dan Bisnis 4(1): 19-31. https://doi.org/10.17358/ jabm.4.1.19.

Wan-Hussin WN. 2009. The impact of family-firm structure and board composition on corporate transparency: Evidence based on segment disclosures in Malaysia. The International Journal of Accounting 44(4): 313-333. https:// doi.org/10.1016/j.intacc.2009.09.003.

Warganegara DL. 2011. The Effect of Multinational Underwriting Firm on Intellectual Capital Disclosure in Indonesia IPO Prospectuses. Jurnal Keuangan dan Perbankan 15(1): 1-14.

Widarjo W. 2011. Pengaruh modal intelektual dan pengungkapan modal intelektual pada nilai perusahaan yang melakukan Initial Public Offering. Jurnal Akuntansi dan Keuangan Indonesia 8(2): 157-170. https://doi. org/10.21002/jaki.2011.10.

Widarjo W, Rahmawati, Bandi, Widagdo AK. 2017. Underwriter reputation, intellectual capital disclosure, and underpricing. International Journal of Business and Society 18(2): 227-244. https://doi.org/10.33736/ijbs.480.2017. 